\title{
TWO NEW MYXOSPOREAN PARASITES (MYXOZOA: MYXOBOLIDAE) FROM THE FRESHWATER FISH PUNTIUS TICTO PUNCTATUS DAY IN KERALA, INDIA
}

\author{
P.K. Sheeja ${ }^{1}$ and K.P. Janardanan ${ }^{2}$ \\ ${ }_{1,2}$ Parasitology Laboratory, Department of Zoology, University of Calicut, Kerala 673635, India \\ Email: ${ }^{2}$ kpjanardanan@yahoo.co.in
}

\begin{abstract}
Two new species of Myxobolus, Myxobolus puntiusi sp. nov. from the heart wall, and Myxobolus ticto sp. nov. from the gills, muscles, intestine and liver of the two-spotted barb, Puntius ticto punctatus Day are described.

KEYWORDS

Myxobolus puntiusi sp. nov., Myxobolus ticto sp. nov., Myxosporea, parasites, Puntius ticto punctatus.
\end{abstract}

Kerala with its vast expanse of water bodies has a rich freshwater fish fauna. The two-spot barb, Puntius ticto punctatus, is a common freshwater fish found in paddy fields, ponds, streams and rivers of Kerala. During the course of an explorative study on the myxosporean fauna of freshwater fishes in the Malappuram district of Kerala, we came across two species belonging to the genus Myxobolus from P. ticto punctatus. The histozoic genus Myxobolus was established by Bütschli (1882) with M. muelleri from Leuciscus cephalus as its type. Subsequently, more than 760 species have been added to this genus from several parts of the world. Of these, more than 100 species are restricted to the Indian subcontinent.

Detailed observations proved that the two species are distinctly different from the known species and, are therefore, reported here as Myxobolus puntiusi sp. nov. and Myxobolus ticto sp. nov.

\section{Materials And Methods}

Fifty-nine Puntius ticto punctatus were collected from paddy fields, ponds, streams and rivers of Malappuram district of Kerala during a 10 month period, from March to December 2005. The collected fishes were brought live to the laboratory, and examined immediately for myxosporean infections or maintained live in cement cisterns. The fishes were killed by cervical rupture and examined under a stereozoom dissecting microscope for any externally visible myxosporeans. Internal organs were dissected out and placed into separate petridishes containing $0.75 \%$ saline and examined under the microscope. Cyst-like plasmodia were carefully isolated, placed in a few drops of saline taken on a slide, ruptured with fine needles, a cover glass was placed over, and observed under phase-contrast objectives of 'Zeiss Axioskop 2 Plus' microscope to study the spores and developmental stages. Contents of gall bladder and urinary bladder were observed without adding saline. Fresh spores were treated with Lugol's iodine for detecting iodinophilous vacuole. India Ink technique, after Lom \& Vavra (1963), was used to reveal any mucous envelopes around the spores. Polar filament extrusion was made using saturated urea solution. For permanent preparations, air-dried smears of spores and development stages were fixed in methanol and stained with Giemsa's stain; Schaudinn's fluid-fixed smears were stained with Heidenhain's iron haematoxylin and counter stained with eosin (Mohr, 1981).

Measurements were taken from fresh materials; on the average 20 spores were measured following the guidelines given by Lom \& Arthur (1989). Measurements are in micrometres $(\mu \mathrm{m})$; mean values are in parentheses. Sketches were made with a prism type camera lucida.

\section{MYXOBOLUS PUNTIUSI SP.NOV.}

(Fig. 1)

\section{Material examined}

Type: iii.2005-xii.2005, Vellimuttam, Malappuram, Kerala, India. Deposited in the parasite collections, Parasitology Laboratory, Department of Zoology, University of Calicut, Kerala, India (No. Z/Par/M (M) O 1). Host: Puntius ticto punctatus Day, Site of infection: Heart wall.

\section{Etymology}

Named after the generic name of the type-host, P. ticto punctatus

\section{Description}

Cyst-like plasmodia: Round or oval, milky-white, with thin walls, found attached to heart wall; measured 249.6-296.4 $\times$ 109.2-140.4 (269.1 × 120.9), contained fully formed spores.

Spores: Ellipsoid to ovoid with broad anterior end in valvular view; lenticular in sutural view; measured 13.5-16.5 $\times 10.5-12.0(15 \times 11.02)$. Spore valves smooth, symmetrical more thickened toward posterior end. Sutural line distinct, with 12 sutural folds, distributed around spore margin. Intercapsular ridge prominent. Polar capsules two, pyriform, slightly unequal. Larger capsules measured 6.75-7.5 × 3-4.5 $(7.08 \times 3.97)$ and smaller 5.25-6.75 × 3-4.5 (5.7 x 3.67). Polar filaments with 7-9 coils in larger capsules and 5-7 coils in smaller capsules. Extruded filaments unequal, uniformly thick, 48-78 (55.7) and 42-57 (49.5) in length. Sporoplasm finely granular, filling almost the entire extracapsular space and contained two nuclei.

Prevalence: Eleven of 59 (18.6\%) fishes examined were infected.

\section{Remarks}

The present myxosporean from the heart wall of Puntius ticto punctatus has ellipsoid to ovoid spores without any posterior processes and two pyriform polar capsules at the anterior end. These characters are significant enough for inclusion of this species under the genus Myxobolus Bütschli, 1882 of the family

Manuscript 1533; @ ZOO; Date of publication 21 December 2006 Received 06 March 2006; Finally accepted 30 September 2006 


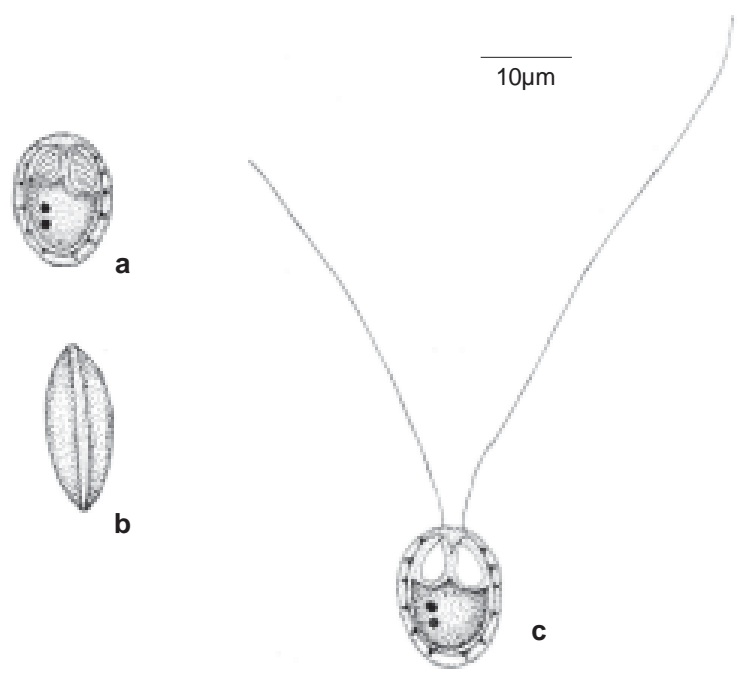

Figure 1. Myxobolus puntiusi sp. nov.
a - Spore - valvular view; b - Spore - sutural view; $c$ - Spore with extruded polar filaments

Myxobolidae Thelohan, 1892.

Myxobolus puntiusi sp. nov. closely resembles M. buri Egusa, 1985 from the brain of Seriola quinqueradiata, M. karuni Masoumian et al., 1994 from primary gill filaments of Barbus grypus and M. bulbocordis Masoumian et al., 1996 from the heart of B. sharpeyi in spore shape, and in the presence of sutural folds and intercapsular ridge. M. buri and M. bulbocordis are different from the present form in spore dimensions and number of sutural folds. Further, equal polar capsules of $M$. buri and M. bulbocordis make them distinctly different. M. karuni also differs in the nature of intercapsular ridge and in having equal polar capsules. In spore dimensions, the present form comes close to $M$. margitae Molnar, 2000 infecting the gill filaments of Alburnus alburnus. But it differs in having unequal polar capsules, and sutural folds. Besides, the site of infection is different. A comparison of characters of the present species with that of the five related species is presented in Table 1. In view of the differences stated above, this species is considered as distinct and named Myxobolus puntiusi sp. nov., after the generic name of the host.

\section{MYXOBOLUS TICTO SP. NOV.}

(Fig. 2)

\section{Material examined}

Type: iii.2005-xii.2005, Vellimuttam, Malappuram, Kerala, India. Deposited in the parasite collections, Parasitology Laboratory, Department of Zoology, University of Calicut Kerala, India (No. Z/Par/M (M) 02). Host: Puntius ticto punctatus Day. Site of infection: Gills, muscles, intestine and liver

Etymology

Named after the species name of the type-host, P. ticto punctatus

\section{Description}

Cyst-like Plasmodia: Round or irregular in outline, milkywhite, found in the gills, muscles, intestine and liver; measured 223-452×215-405 (317×284). Most plasmodia contained fully formed spores.

Spores: Oval to pyriform with moderately pointed anterior end in valvular view and lenticular in sutural view; measured $12.75-15 \times 7.75-9(14.55 \times 7.8)$. Spore valves symmetrical, smooth, meet along a distinctly raised sutural ridge, more thickened toward posterior end; sutural folds $6-8$, in posterior one-third of spore. Polar capsules two, pyriform, equal; measured 4.7-7.5 ×2.25-3.0 (6.63×2.92). Each capsule enclosed 6-8 coils of polar filament; extruded filaments equal, uniformly thick, 42-52.5 (43.87) long. Sporoplasm finely granular, contained two nuclei.

Prevalence: Twenty of $59(29.5 \%)$ fishes examined were infected.

Table 1. Comparative characters of Myxobolus puntiusi sp. nov. and of the four related species.

\begin{tabular}{|c|c|c|c|c|c|c|c|c|c|c|}
\hline Species & LS & BS & LPC & BPC & NC & $\begin{array}{l}\text { Inter- } \\
\text { capsular } \\
\text { ridge }\end{array}$ & $\begin{array}{l}\text { No.of } \\
\text { sutural } \\
\text { folds }\end{array}$ & $\begin{array}{l}\text { Site of } \\
\text { infection }\end{array}$ & Hosts & References \\
\hline $\begin{array}{l}\text { Myxobolus buri } \\
\text { Egusa, } 1985\end{array}$ & $\begin{array}{l}9.2-11.8 \\
(10.6)\end{array}$ & $\begin{array}{l}7.9-10.2 \\
(9.2)\end{array}$ & $\begin{array}{l}3.9-5.4 \\
(4.5)\end{array}$ & $\begin{array}{l}3.2-3.9 \\
(3.4)\end{array}$ & 3 & Small & 9 & Brain & $\begin{array}{l}\text { Seriola } \\
\text { quinqueradiata }\end{array}$ & Egusa (1985) \\
\hline $\begin{array}{l}\text { Myxobolus karuni } \\
\text { Masoumian et al.,1994 }\end{array}$ & $\begin{array}{l}13-14.9 \\
(14.1)\end{array}$ & $\begin{array}{l}9.7-10.4 \\
(10.2)\end{array}$ & $\begin{array}{l}6.5-7.5 \\
(6.2)\end{array}$ & $\begin{array}{l}5.2-6.3 \\
(5.8)\end{array}$ & $10-11$ & Long & 4 & Gills & Barbus grypus* & $\begin{array}{l}\text { Masoumian et al. } \\
\text { (1994) }\end{array}$ \\
\hline $\begin{array}{l}\text { Myxobolus bulbocordis } \\
\text { Masoumian et al.,1996 }\end{array}$ & $\begin{array}{l}17.3-19.6 \\
(19)\end{array}$ & $\begin{array}{l}13.8-15.5 \\
(15.3)\end{array}$ & $\begin{array}{l}8.1-9.2 \\
(8.4)\end{array}$ & $\begin{array}{l}2.8-3.2 \\
(3)\end{array}$ & $8-9$ & Distinct & 9 & Heart & $\begin{array}{l}\text { Barbus } \\
\text { sharpeyi**}\end{array}$ & $\begin{array}{l}\text { Masoumian } \\
\text { et al. (1996) }\end{array}$ \\
\hline $\begin{array}{l}\text { Myxobolus margitae } \\
\text { Molnar, } 2000\end{array}$ & $\begin{array}{l}13-14 \\
(13.7)\end{array}$ & $\begin{array}{l}9.5-10 \\
(9.7)\end{array}$ & $\begin{array}{l}4.5-5.5 \\
(5)\end{array}$ & $\begin{array}{l}3-4.5 \\
(3.97)\end{array}$ & $7-8$ & Large & - & $\begin{array}{l}\text { Gill } \\
\text { filaments }\end{array}$ & $\begin{array}{l}\text { Alburnus } \\
\text { alburnus }\end{array}$ & Molnar (2000) \\
\hline \multirow[t]{2}{*}{$\begin{array}{l}\text { Myxobolus puntiusi } \\
\text { sp. nov. }\end{array}$} & $\begin{array}{l}13.5-16.5 \\
(15)\end{array}$ & $\begin{array}{l}10.5-12 \\
(11.02)\end{array}$ & $\begin{array}{l}\text { Larger } \\
6.75-7.5 \\
(7.08)\end{array}$ & $\begin{array}{l}3-4.5 \\
(3.67)\end{array}$ & $7-9$ & Prominent & 12 & Heart wall & $\begin{array}{l}\text { Puntius ticto } \\
\text { punctatus }\end{array}$ & \\
\hline & & & $\begin{array}{l}\text { Smaller } \\
5.25-6.75 \\
(5.7)\end{array}$ & & $5-7$ & & & & & \\
\hline
\end{tabular}

BPC - Breadth of polar capsule; BS - Breadth of spore; LPC - Length of polar capsule; LS - Length of spore; NC - Number of coils of polar filament. *Junior synonym of Puntius grypus; ** Junior synonym of Puntius sharpeyi 


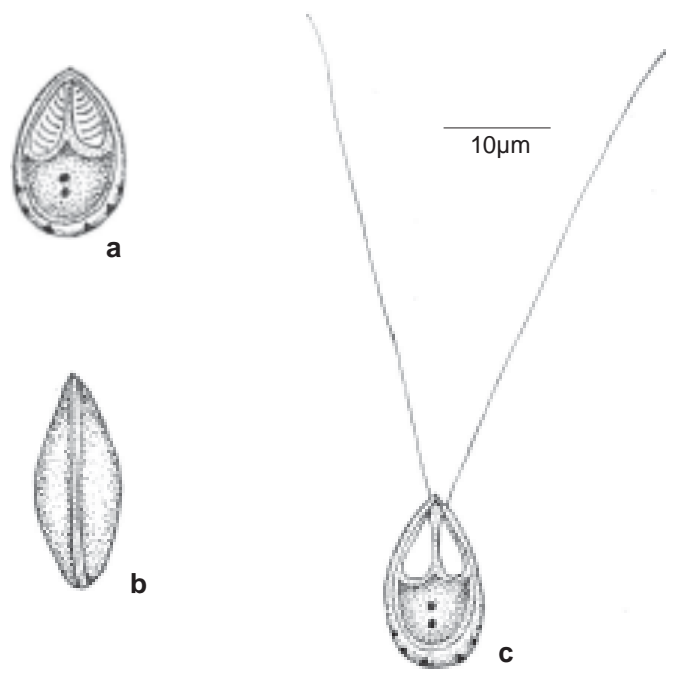

Figure 2. Myxobolus ticto sp. nov.

a - Spore - valvular view; b - Spore - sutural view; $c$ - Spore with extruded polar filaments

\section{Remarks}

The present myxosporean from the gills, intestine, muscles and liver of Puntius ticto punctatus comes close to M. cyprini Doflein, 1898 from the intestine, liver, kidney, pancreas and muscles of Cyprinus carpio, M. anisocapsularis Schulman, 1962 from the gill lamellae of Hemibarbus labeo, M. mahendrae Sarkar, 1986 from the gill arch epithelium of Catla catla and M. cognati Cone et al., 1996 from the operculum and pectoral fins of Cottus cognatus in the size of spores and polar capsules and in the nature of spore valves. Absence of sutural folds in the spores of $M$. cyprini and $M$. anisocapsularis make them different from the present form which has 6-8 sutural folds in the posterior one-third of the spore. Besides, the overlapping polar capsules of $M$. cyprini and spore shape of $M$. anisocapsularis make them distinct. The other two species $M$. mahendrae and $M$. cognati are different in having uniformly thickened spore valves; in addition, M. mahendrae has truncated anterior end and M. cognati has the sutural folds which are distributed all around spore margin. The present Myxobolus deserves comparison with $M$. exiguus Thelohan, 1895 from the gills of Abramis brama and tissue of stomach and pyloric caeca of Mugil capito and M. chelo in spore shape. But it differs in spore dimensions and in absence of intercapsular ridge. A comparative study of characters of the present form and that of the above related species presented in Table 2 shows that the present form is distinctly different from the other five species. In view of the differences in morphology and morphometry, the species under discussion is considered as new and named Myxobolus ticto sp. nov., after the species name of the type-host.

\section{REFERENCES}

Bütschli, O. (1882). Myxosporidia, pp. 590-603. In: Bronn's Klass Ordn; des Tierreiches, Protozoa 1.

Doflein, F. (1898). Studien zur naturgeschichte der protozoen. III. Uber myxosporidien. Zool. Jahrb Anatomy 2: 281-350.

Cone, D.K., R.G. Stickel, G.W. Eck \& P.M. Muzzal (1996). Myxobolus cognati n.sp.(Myxosporea) from the opercular integument of Cottus cognatus (Cottidae) in Lake Michigan. Journal of Parasitology 82(1): 137139.

Egusa, S. (1985). Myxobolus buri sp.n. (Myxosporea: Bivalvulida) parasitic in the brain of Seriola quinqueradita Temminck et Schlegel. Fish Pathology 14(4): 239-244.

Lom, J. \& J.R. Arthur (1989). A guideline for the preparation of species descriptions in Myxosporea. Journal of Fish Diseases 12: 151-156.

Lom, J. \& J. Vavra (1963). Mucous envelops of the spores of the subphylum Cnidospora (Doflein, 1901). Vestnik Ceskoslovenske spolecnosti

Table 2. Comparative characters of Myxobolus ticto sp.nov and of the five related species.

\begin{tabular}{|c|c|c|c|c|c|c|c|c|c|}
\hline Species & LS & BS & LPC & BPC & NC & $\begin{array}{l}\text { Number } \\
\text { of sutural } \\
\text { folds }\end{array}$ & $\begin{array}{l}\text { Site of } \\
\text { infection }\end{array}$ & Hosts & References \\
\hline $\begin{array}{l}\text { Myxobolus exiguus } \\
\text { Thelohan, } 1895\end{array}$ & 8-12 & $6-9.3$ & $4-7$ & $2.5-2.7$ & - & 3 & $\begin{array}{l}\text { Gills } \\
\text { Tissue of stomach and } \\
\text { pyloric caeca }\end{array}$ & $\begin{array}{l}\text { Abramis brama } \\
\text { Mugil capito and } \\
\text { M. chelo }\end{array}$ & $\begin{array}{l}\text { Thelohan } \\
(1895)\end{array}$ \\
\hline $\begin{array}{l}\text { Myxobolus cyprini } \\
\text { Doflein, } 1898\end{array}$ & $10-16$ & $8-12$ & $5.2-7$ & - & - & - & $\begin{array}{l}\text { Intestine, liver, kidney, } \\
\text { pancreas and muscles }\end{array}$ & Cyprinus carpio & $\begin{array}{c}\text { Doflein } \\
(1898)\end{array}$ \\
\hline $\begin{array}{l}\text { Myxobolus anisocapsularis } \\
\text { Shulman, } 1962\end{array}$ & $15-15.5$ & 7.7-8.4 & $\begin{array}{l}\text { Larger } \\
6-8.5 \\
\text { Smaller } \\
2.5-4\end{array}$ & $\begin{array}{l}4 \\
2.5-4\end{array}$ & $\begin{array}{l}- \\
-\end{array}$ & $\begin{array}{l}- \\
-\end{array}$ & Gill lamellae & Hemibarbus labeo & $\begin{array}{l}\text { Shulman } \\
(1962)\end{array}$ \\
\hline $\begin{array}{l}\text { Myxobolus mahendrae } \\
\text { Sarkar, } 1986\end{array}$ & $\begin{array}{l}11.52- \\
13.96 \\
(12.7)\end{array}$ & $\begin{array}{l}9.77- \\
10.47 \\
(10.37)\end{array}$ & $\begin{array}{l}\text { Larger } \\
6.28-7.33 \\
(6.98) \\
\text { Smaller } \\
4.19-6.98 \\
(5.44) \\
5.5-7.5 \\
(6.6)\end{array}$ & $\begin{array}{l}3.49-4.19 \\
(3.73) \\
\\
3.14-3.49 \\
(3.42)\end{array}$ & $\begin{array}{l}\text { 7-9 } \\
5-6\end{array}$ & $5-6$ & Gillarch & Catla catla & Sarkar (1986) \\
\hline $\begin{array}{l}\text { Myxobolus cognati } \\
\text { Cone et al., } 1996\end{array}$ & $\begin{array}{l}2-14 \\
(13.3)\end{array}$ & $\begin{array}{l}9.5-10.5 \\
(10)\end{array}$ & $\begin{array}{l}8.1-9.2 \\
(8.4)\end{array}$ & $\begin{array}{l}3 \\
(3)\end{array}$ & $8-11$ & $6-8$ & $\begin{array}{l}\text { Operculum and pectoral } \\
\text { fins }\end{array}$ & Cottus cognatus & $\begin{array}{l}\text { Cone et al. } \\
(1996)\end{array}$ \\
\hline Myxobolus ticto sp. nov. & $\begin{array}{l}12.75- \\
15 \\
(14.55)\end{array}$ & $\begin{array}{l}6.75-9 \\
(7.8)\end{array}$ & $\begin{array}{l}4.5-7.5 \\
(6.63)\end{array}$ & $\begin{array}{l}25-3 \\
(2.92 .)\end{array}$ & $6-8$ & $6-8$ & $\begin{array}{l}\text { Gills, muscles, intestine } \\
\text { and liver }\end{array}$ & $\begin{array}{l}\text { Puntius ticto } \\
\text { punctatus }\end{array}$ & \\
\hline
\end{tabular}

BPC - Breadth of polar capsule; BS - Breadth of spore; LPC - Length of polar capsule; LS - Length of spore; NC - Number of coils of polar filament. 
Zoologicke Acta Societatis Zoologicae Bohemoslovenicae 27(1): 4-6. Masoumian, M., F. Baska \& K. Molnar (1994). Description of Myxobolus karuni sp.n. and Myxobolus persicus sp.n. (Myxosporea: Myxozoa) from Barbus grypus of the River Karun, Iran. Parsitogica Hungarica 27: 21-26. Masoumian, M., F. Baska \& K. Molnar (1996). Description of Myxobolus bulbocordis sp.nov. (Myxosporea: Myxobolidae) from the heart of Barbus sharpeyi (Günther) and histo-pathological changes produced by the parasite. Journal of Fish Diseases 19: 15-21.

Mohr, J.L. (1981). Methods for Protozoa, pp. 281-309. In: Clark, G. (ed.). Staining Procedures. Williams and Wilkins, Baltimore.

Molnar, K. (2000). Survey on Myxobolus infection of the bleak (Alburnus alburnus L.) in the river Danube and Lake Balaton. Acta Veteinaria Hungarica 48(4): 421-432.

Sakar, N.K. (1986). On two new species of Myxobolus Bütschli, 1882 (Myxozoa: Myxosporea) from the freshwater fishes of West Bengal, India. Acta Protozoologica 25(2): 235-239.

Shulman, S.S. (1962). Myxosporidia (Myxosporidia), pp. 47-130. In: Operdeitel Prenovodnykh Ryb SSSR. Izd. AN SSSE, Moscow-Leningrad.

Thelohan, P. (1895). Recherches surles Myxosporidies. Bulletin of Science. Fr. Belgium 26: 100-394.

\section{ACKNOWLEDGEMENTS}

One of the authors (P.K. Sheeja) is grateful to the CSIR, New Delhi for providing financial assistance in the form of Junior and Senior Fellowships.

\section{Bombay Natural History Society}

Requires

\section{RESEARCH OFFICER for ENVIS Centre}

Educational Qualifications: The candidate should be I class Graduate / Post Graduate in Life Sciences/ Zoology/Botany/Microbiology. Candidates having knowledge of computer systems like MS office, web designing, DTP, good communication skills and interest in wildlife research will be given preference. Good communication skill in English essential.

Location: The post is based in BNHS Head office at Mumbai.

Job Description:

- Handling database - Avian Ecology and Inland wetlands

- Maintenance of database

- Providing technical support for Newsletter publication and website maintenance

- Coordination with the BNHS Library

- Assisting Information Officer in answering the queries

\section{Age Limit: Up to 30 years \\ Salary: Negotiable}

The appointment will be initially for one year on contract basis. Candidates fulfilling the above requirements may send their applications with detailed bio-data and expected salary within 15 days to:

\section{Director}

Bombay Natural History Society, Hornbill House, Shaheed Bhagat Singh Road, Mumbai 400023, Maharashtra

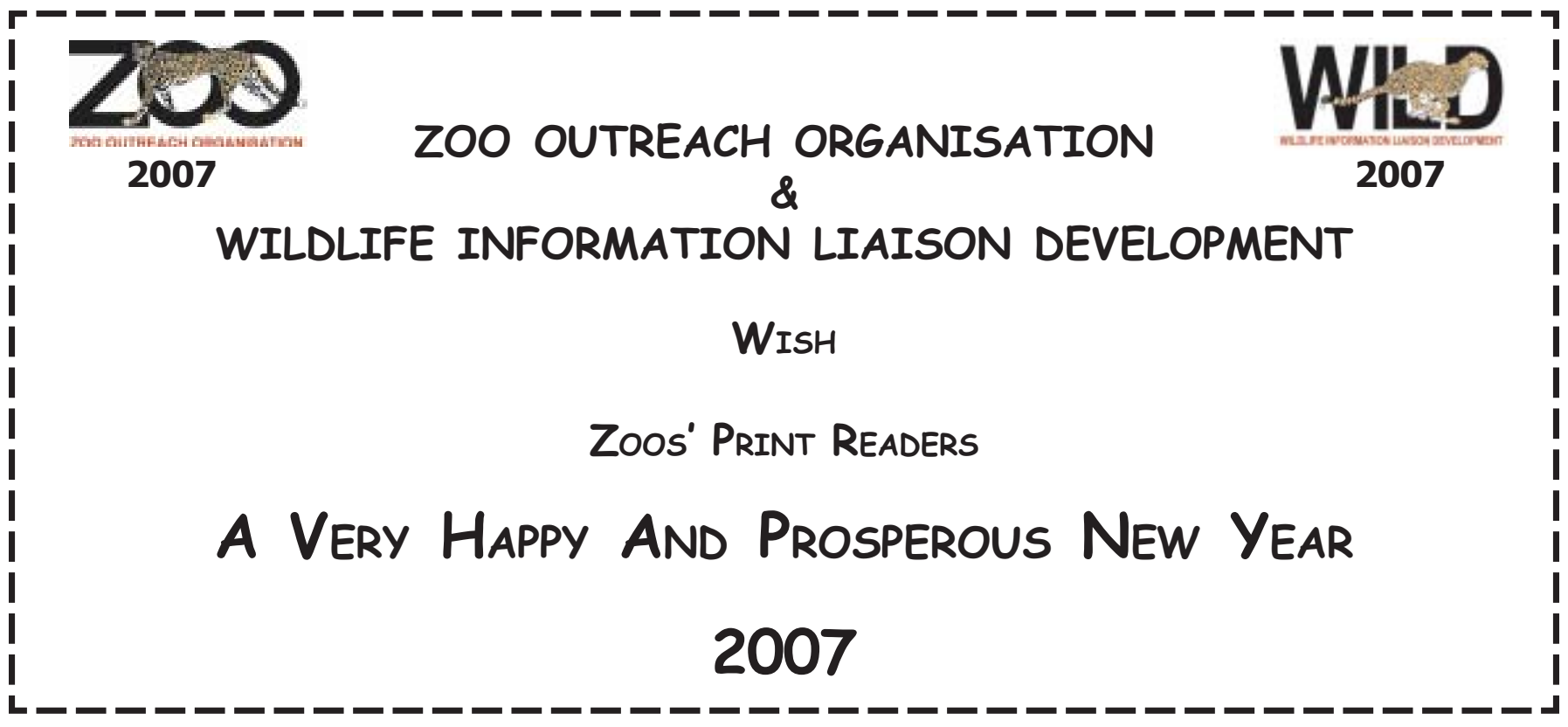

